\title{
Extremely halophilic denitrifying bacteria from hypersaline inland lakes, Halovibrio denitrificans sp. nov. and Halospina denitrificans gen. nov., sp. nov., and evidence that the genus name Halovibrio Fendrich 1989 with the type species Halovibrio variabilis should be associated with DSM 3050
}

\author{
Correspondence \\ D. Yu. Sorokin \\ soroc@inmi.host.ru or \\ D.Y.Sorokin@tnw.tudelft.nl
}

\author{
D. Yu. Sorokin, ${ }^{1,2}$ T. P. Tourova, ${ }^{1}$ E. A. Galinski, ${ }^{3}$ C. Belloch ${ }^{4} \dagger$ \\ and B. J. Tindall ${ }^{4}$
${ }^{1}$ Winogradsky Institute of Microbiology, Russian Academy of Sciences, Prospect 60-let Octyabrya 7/2, 117811 Moscow, Russia
${ }^{2}$ Department of Environmental Biotechnology, Delft University of Technology, Julianalaan 67, 2628 BC Delft, The Netherlands
${ }^{3}$ Institute of Microbiology and Biotechnology, Rheinische Friedrich-Wilhelms University, Meckenheimer Allee 168, D-53115 Bonn, Germany

${ }^{4} \mathrm{DSMZ}$ - Deutsche Sammlung von Mikroorganismen und Zellkulturen GmbH, Mascheroder Weg 1b, D-38124 Braunschweig, Germany

\begin{abstract}
Anaerobic enrichments with acetate as electron donor and nitrate as electron acceptor at $4 \mathrm{M} \mathrm{NaCl}$ from inland, hypersaline lake sediments from Central Asia resulted in the isolation of several extremely halophilic bacteria that comprised two subgroups, most with vibrio-shaped cells and a single strain with rod-shaped cells. Members of both subgroups were extremely halophilic, with growth occurring in 2-5 M NaCl with an optimum at 2-3 M. 16S rRNA gene sequence analysis showed a close affiliation of the new isolates with Pseudomonas halophila DSM 3050 in the Gammaproteobacteria. However, phenotypic comparison of the denitrifying halophiles with the original description of $P$. halophila demonstrated that they were more similar to another bacterium isolated from the same source at the same time, the extremely halophilic Halovibrio variabilis, which has since been reclassified as Halomonas variabilis (DSM 3051). Direct cross-comparison showed that the characteristics of these two halophilic bacteria do not correspond with the original descriptions associated with these names and DSM numbers. While it is desirable that this problem be solved, in connection with the present investigations, this is a matter that can only be solved by a Request for an Opinion. On the basis of the phenotypic and genetic comparison of these isolates, it is proposed that the new denitrifying vibrio-shaped isolates represent a novel species, Halovibrio denitrificans sp. nov. (type strain $\mathrm{HGD} 3^{\top}=\mathrm{DSM} 15503^{\top}=\mathrm{UNIQEM} \mathrm{U232} 2^{\top}$ ) and that the rod-shaped isolate represents a novel genus and species, Halospina denitrificans

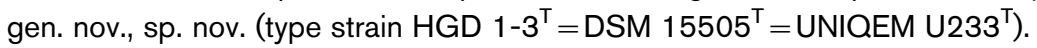

Inland salt lakes, especially those with a salt content close to saturation, represent a unique type of extreme environment

Published online ahead of print on 28 October 2005 as DOI 10.1099/ ijs.0.63964-0.

†Present address: Instituto de Agroquímica y Tecnologìa de Alimentos (IATA), Apdo. 73, 46100 Burjassot, Valencia, Spain.

The GenBank/EMBL/DDBJ accession numbers for the 16S rRNA gene sequences of strains HGD $3^{\top}$ and HGD $1-3^{\top}$ are DQ072718 and DQ072719, respectively. dominated by a limited number of prokaryotes equipped with special adaptations for a life in brine. The aerobic heterotrophic conditions at near-saturating salt concentrations (3-5 M NaCl) usually favour extremely halophilic haloarchaea (Oren, 2002). The opportunistic strategy is represented here by the moderately halophilic/extremely salt-tolerant Halomonas species (Gammaproteobacteria) that are better adapted to fluctuating salinity, whereas an extremely halophilic phenotype able to compete with the haloarchaea at salt-saturating conditions is very rare among 
the eubacteria (Ventosa et al., 1998). One possibility by which the eubacteria can compete with the haloarchaea for organic electron donors is their capacity to denitrify using simple organic electron donors produced in anaerobic sediments (such as acetate), since this potential is much more common for bacteria than for archaea (Zumft, 1997). Denitrification at extremely high salt concentrations represents an important function both for natural hypersaline habitats and as a potential application in the biological treatment of high-salt industrial waste rich in nitrate (Clifford \& Liu, 1993). Furthermore, as mentioned above, the extremely halophilic eubacteria with a salt range for growth equal to that of haloarchaea, in contrast to moderate halophiles, are currently only poorly characterized. Here we report the results of the characterization of a group of gammaproteobacteria that persistently dominated in enrichment cultures at $4-5 \mathrm{M} \mathrm{NaCl}$ with acetate as electron donor/carbon source and nitrate $/ \mathrm{N}_{2} \mathrm{O}$ as electron acceptor, inoculated with sediments from hypersaline lakes in Central Asia.

Dry steppe areas in south-western Siberia and north-eastern Mongolia harbour numerous small, hypersaline chloridesulfate lakes, with a salt concentration approaching saturation. We investigated more than 20 such lakes in the Kulunda Steppe (Altai, Russia) stretching over $800 \mathrm{~km}$ along the central eastern border of Kazachstan, and two lakes in the north-eastern Mongolian steppe. Sediment samples from the Kulunda lakes were combined in six groups according to the salt content, which varied from 10 to $38 \%(\mathrm{w} / \mathrm{v})$. The salt content of the Mongolian lakes was $20-25 \%$. The $\mathrm{pH}$ ranged from $7 \cdot 5$ to $8 \cdot 2$ and the dominant ions were $\mathrm{Na}^{+}, \mathrm{Cl}^{-}$and $\mathrm{SO}_{4}^{2-}$.

Extremely halophilic denitrifying bacteria were enriched and isolated in pure culture using the following mineral base medium $\left(\mathrm{g} \mathrm{l}^{-1}\right)$ : $\mathrm{NaCl}, 240 ; \mathrm{K}_{2} \mathrm{HPO}_{4}, 2 \cdot 5 ;\left(\mathrm{NH}_{4}\right)_{2} \mathrm{SO}_{4}, 0 \cdot 5$. The $\mathrm{pH}$ was adjusted to $7 \cdot 2$. After sterilization, the medium was supplemented with $10 \mathrm{mM}$ sodium acetate, $0 \cdot 1 \mathrm{~g}$ yeast extract $\mathrm{l}^{-1}, 2 \mathrm{mM} \mathrm{MgCl} 2 \cdot 6 \mathrm{H}_{2} \mathrm{O}$ and $1 \mathrm{ml} \mathrm{l}^{-1}$ of a trace metal solution (Pfennig \& Lippert, 1966). $\mathrm{KNO}_{3}(5 \mathrm{mM}$ ) or $\mathrm{N}_{2} \mathrm{O}(50 \mathrm{mM})$ was used as the electron acceptor. The medium was made anoxic by five sequential cycles of evacuation-flushing with argon. Incubation was performed in $100 \mathrm{ml}$ serum bottles sealed with butyl rubber stoppers, with $80 \mathrm{ml}$ medium at $30^{\circ} \mathrm{C}$. Growth was monitored by measuring optical density at $600 \mathrm{~nm}$ and qualitative tests for nitrate/nitrite (Merck). After several 1:100 transfers and serial dilutions, pure cultures were isolated from single colonies on solid medium with the same composition as the base medium except that the $\mathrm{NaCl}$ concentration was reduced to $2 \mathrm{M}$. The plates were incubated in closed jars under argon or argon plus $10 \% \mathrm{~N}_{2} \mathrm{O}$ in the presence of an oxygen-scavenging catalyst (AnaeroGen; Oxoid).

Nitrogen and sulfur compounds and protein were analysed as described previously (Sorokin et al., 2001). Intracellular compatible solutes were extracted and analysed following a modification of the methods described by Galinski \& Herzog (1990). Phase-contrast micrographs were obtained using a Zeiss Axioplan Imaging 2 microscope. Cells were fixed with glutaraldehyde (final $3 \%, v / v$ ) for electron microscopy and positively contrasted with $1 \%(\mathrm{w} / \mathrm{v})$ uranyl acetate. Isolation of DNA and subsequent determination of the $\mathrm{G}+\mathrm{C}$ content and DNA-DNA hybridization were performed by using the thermal denaturation/reassociation technique (Marmur, 1961; De Ley et al., 1970). Respiratory lipoquinones and polar lipids were extracted and analysed as described by Tindall (1990). Fatty acid methyl esters were obtained from freeze-dried whole cells using the method of Labrenz et al. (1998). The fatty acid methyl esters were separated and identification was confirmed by GC-MS, as described previously (Strömpl et al., 1999). DNA was obtained by standard phenol/chloroform extraction for amplification and sequencing of 16S rRNA genes. The 16S rRNA genes were selectively amplified using primers $5^{\prime}$ AGAGTTTGATCCTGGCTCAG-3' (forward) and 5'-TACGGTTACCTTGTTACGACTT-3' (reverse). PCR products were purified from low-melting-point agarose using the Wizard PCR-Prep kit (Promega), according to the manufacturer's instructions. Almost complete sequencing (14001450 nucleotides) was performed using the Promega Silver sequencing kit, according to the manufacturer's instructions with minor modifications. Phylogenetic analysis based on nucleotide sequences of 16S rRNA genes was performed using various treeing algorithms realized in the TREECON (Van de Peer \& De Wachter, 1994) and PHYLIP (Felsenstein, 1989) software packages. Pairwise evolutionary distances (expressed as estimated changes per 100 nucleotides) were computed using the Jukes and Cantor method (Jukes \& Cantor, 1969). The resulting phylogenetic tree was constructed by using the neighbour-joining method. Bootstrap analysis (100 replications) was used to validate the reproducibility of the branching pattern of the trees.

Anaerobic enrichments with acetate and nitrate at moderate salinity $(2 \mathrm{M} \mathrm{NaCl})$, inoculated with the sediment samples from hypersaline lakes in Altai and Mongolia, resulted in the domination of Halomonas spp. (identified by partial $16 \mathrm{~S}$ rRNA gene sequencing; data not shown). In contrast, in most of the enrichments at $4 \mathrm{M} \mathrm{NaCl}$ the halomonads were out-competed by other gammaproteobacteria. These enrichments were the source of four pure cultures of extremely halophilic denitrifiers, three with nitrate and one with $\mathrm{N}_{2} \mathrm{O}$ as electron acceptor. Strains HGD 2, HGD $3^{\mathrm{T}}$ (nitrate) and HGDK $5\left(\mathrm{~N}_{2} \mathrm{O}\right)$ were represented by vibrio-toshort spirilla (Fig. 1a) that were motile with a single polar flagellum (Fig. 2a). They showed high DNA-DNA hybridization values with each other $(>80 \%)$, indicating specieslevel relatedness. Strain HGD $1-3^{\mathrm{T}}$ (nitrate) is a long, flexible, non-motile rod (Figs $1 \mathrm{~b}$ and $2 \mathrm{~b}$ ). It showed only $15-20 \%$ DNA-DNA hybridization with the vibrio-shaped strains, indicating low genetic relatedness (and differences at the genomic level).

All strains were facultatively anaerobic and grew with acetate within the range $2-5 \mathrm{M} \mathrm{NaCl}$ aerobically and anaerobically with nitrate. The vibrio-shaped strains grew optimally in 

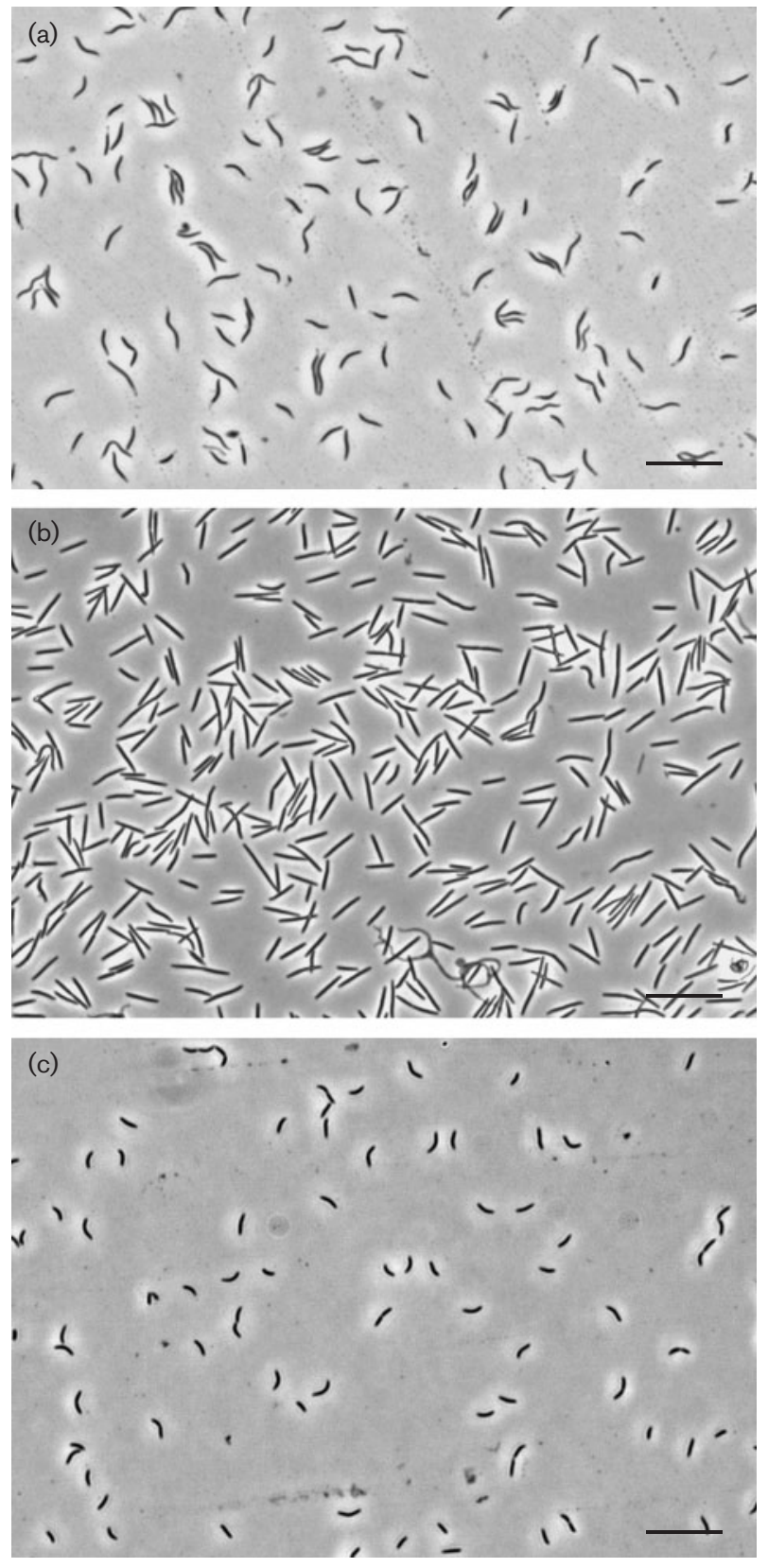

Fig. 1. Phase-contrast micrographs showing the morphologies of cells of strains HGD $3^{\top}(a), H G D 1-3^{\top}$ (b) and DSM 3050 (c) grown in $3 \mathrm{M} \mathrm{NaCl}$. Bars, $10 \mu \mathrm{m}$.

$2-2 \cdot 5 \mathrm{M} \mathrm{NaCl}$ and strain HGD $1-3^{\mathrm{T}}$ in $2 \cdot 5-3 \mathrm{M} \mathrm{NaCl}$. The new isolates all accumulated large amounts of nitrite (up to $90 \%$ from added nitrate) and $\mathrm{N}_{2} \mathrm{O}$ (up to $30 \%$ from added nitrate) during anaerobic growth with nitrate, which increased with increasing salinity of the medium. To prevent nitrite inhibition, nitrate was supplied in amounts not greater than $5 \mathrm{mM}$. Despite the obvious repression of nitrite and $\mathrm{N}_{2} \mathrm{O}$ reduction by extremely high salt, experiments with washed cells demonstrated that reduction of all three oxyanions (nitrate, nitrite and $\mathrm{N}_{2} \mathrm{O}$ ) was maximal at high salt
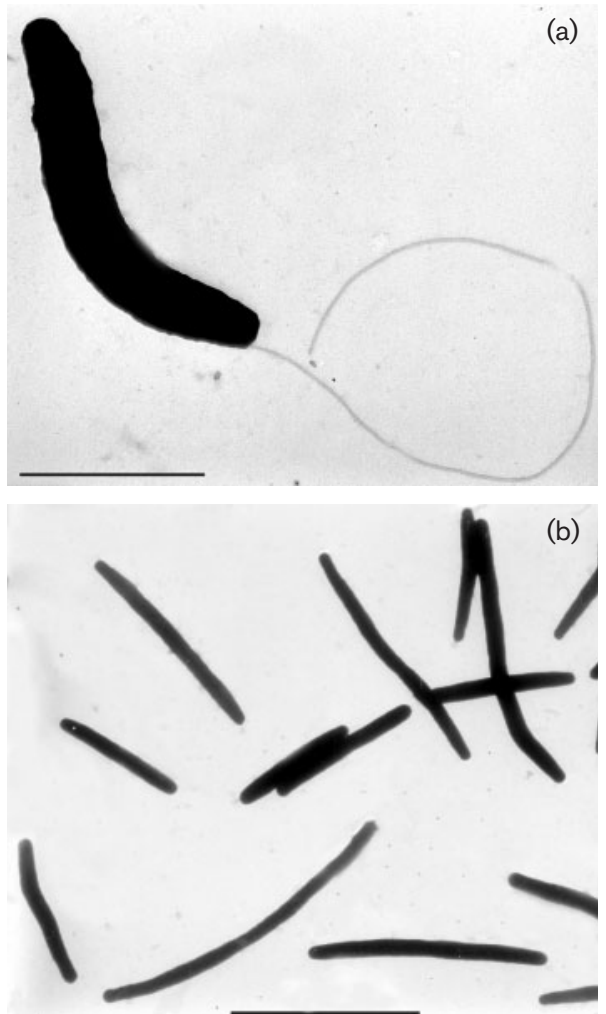

Fig. 2. Electron micrographs showing the morphologies of cells of strains HGD $3^{T}$ (a) and $\mathrm{HGD} 1-3^{\top}$ (b) grown in $3 \mathrm{M} \mathrm{NaCl}$ and positively stained with uranyl acetate. Bars, $1 \mu \mathrm{m}$ (a) and $5 \mu \mathrm{m}$ (b).

(2-3 M), indicating more complex salt effects on anaerobic growth than simple enzyme inhibition (data not shown). Strains isolated with nitrate as electron acceptor grew anaerobically only in the presence of nitrate and with nitrite (at concentrations $<3 \mathrm{mM}$ ), but not with $\mathrm{N}_{2} \mathrm{O}$, despite evidence indicating consumption of the latter by the cultures and by washed cells grown with nitrate. Only strain HGDK 5, which was enriched and isolated with $\mathrm{N}_{2} \mathrm{O}$ as electron acceptor, grew with both nitrate and $\mathrm{N}_{2} \mathrm{O}$. It was found that $\mathrm{N}_{2} \mathrm{O}$ reduction in the strains isolated demanded a higher $\mathrm{pH}$ than that for nitrate reduction ( $\mathrm{pH}$ optimum 9.0 versus $7 \cdot 5$, respectively). This might be one of the problems for growth of extremely halophilic, neutrophilic denitrifiers with $\mathrm{N}_{2} \mathrm{O}$, in contrast to haloalkaliphilic denitrifying members of the genus Halomonas obtained from soda lakes (unpublished results).

One of the main properties of halophilic bacteria is their ability to accumulate large amounts of haloprotecting osmolytes (compatible solutes) during growth in high salt. In members of the Gammaproteobacteria, the most common osmolytes are represented by glycine betaine and ectoines (Galinski, 1995). Analysis of strains HGD $3^{\mathrm{T}}$ and HGD 1-3 ${ }^{\mathrm{T}}$ demonstrated the presence of both osmolytes with domination of the former. When grown in $4 \mathrm{M} \mathrm{NaCl}$ aerobically 
with acetate, cells of strains HGD $3^{\mathrm{T}}$ and HGD $1-3^{\mathrm{T}}$ contained 22 and $17 \cdot 7 \%$ glycine betaine and $2 \cdot 8$ and $3 \cdot 1 \%$ ectoine (weight per weight dry cells), respectively. This differentiates the new isolates from the moderately halophilic Halomonas species, which contain ectoine and hydroxyectoine as the dominant osmolytes (Wohlfarth et al., 1990).

16S rRNA gene sequence analysis placed strains HGD $3^{\mathrm{T}}$ and HGD $1-3^{\mathrm{T}}$ in a cluster with the moderately halophilic bacterium Pseudomonas halophila DSM 3050 (Anzai et al., 2000), which was isolated from the Great Salt Lake, Utah (Fendrich, 1988) (Fig. 3). However, phenotypic comparison of our isolates with the original description of $P$. halophila demonstrated large differences. In fact, the properties of the vibrio-shaped isolates showed a better match with the phenotype of Halovibrio variabilis (Fig. 1c), an extremely halophilic bacterium that was isolated from the same lake and described together with $P$. halophila by the same author (Fendrich, 1988). Strain DSM 3051 was later reclassified, on the basis of 16S rRNA gene sequence data, as Halomonas variabilis (Dobson et al., 1993; Dobson \& Franzmann, 1996). Therefore, we suspected that the two halophiles from the
Great Salt Lake, P. halophila and Halovibrio variabilis, represented by strains DSM 3050 and DSM 3051, respectively, may not correspond with their original descriptions. To verify this hypothesis, both strains were obtained from the DSMZ, cultivated and cross-compared with the new isolates and with their original descriptions. The results (Table 1) confirmed our suspicion that strain DSM 3050 (Fig. 1c), deposited under the name $P$. halophila, in fact matches the original description of the extremely halophilic Halovibrio variabilis, whereas strain DSM 3051 (deposited as Halomonas variabilis) matches the original description of the moderately halophilic $P$. halophila. There was only one important difference between our vibrio-shaped isolates and the original description of Halovibrio variabilis, namely that the latter was described as an obligate aerobe. On checking the ability of strain DSM 3050 to grow anaerobically with acetate and nitrate in $2-4 \mathrm{M} \mathrm{NaCl}$, a positive result was obtained, although the strain grew less actively than the new isolates and the intermediate nitrite was never reduced completely. Apparently, this important feature was overlooked by Fendrich (1988). Also, we were unable to confirm the presence of proteolytic activity in strain DSM 3050, nor was it detected in the new isolates. Franzmann \& Tindall

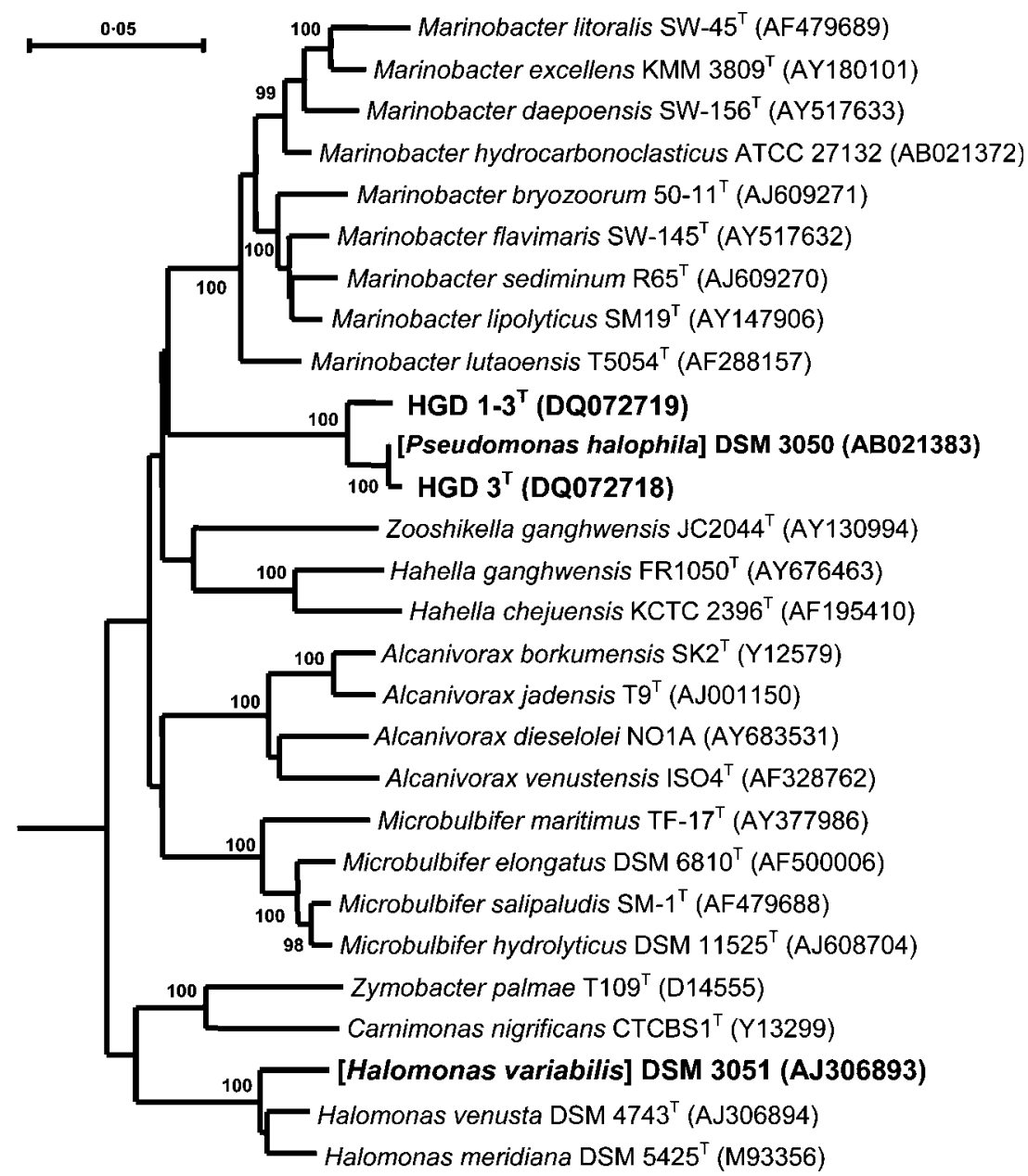

Fig. 3. Phylogenetic positions of extremely halophilic, denitrifying bacteria from hypersaline lakes within the Gammaproteobacteria, based on 16S rRNA gene sequence analysis. The tree was reconstructed from evolutionary distances by using the neighbour-joining method. Bar, 5 inferred nucleotide changes per 100 nucleotides. Percentage bootstrap values were derived from 100 resampling; values greater than $95 \%$ were considered significant. 
Table 1. Comparison of the characteristics of extremely halophilic denitrifying isolates from hypersaline lakes with those of P. halophila DSM 3050 and Halomonas variabilis DSM 3051

\begin{tabular}{|c|c|c|c|c|c|c|c|}
\hline \multirow[t]{2}{*}{ Characteristic } & \multirow{2}{*}{$\begin{array}{c}\text { DSM } 3050 \\
(P . \text { halophila })\end{array}$} & \multirow{2}{*}{$\begin{array}{l}\text { Halovibrio variabilis } \\
\text { (original description) }\end{array}$} & \multirow{2}{*}{$\begin{array}{c}\text { DSM } 3051 \\
\text { (Halomonas } \\
\text { variabilis) }\end{array}$} & \multirow{2}{*}{$\begin{array}{c}\text { P. halophila } \\
\text { (original } \\
\text { description) }\end{array}$} & \multicolumn{3}{|c|}{ Extremely halophilic denitrifying isolates } \\
\hline & & & & & HGD $1-3^{T}$ & HGD $3^{T}$ & HGDK 5 \\
\hline DNA $\mathrm{G}+\mathrm{C}$ content $(\mathrm{mol} \%)$ & $61 \cdot 6$ & $61 \pm 1$ & 58 & $57 \pm 1$ & $60 \cdot 1$ & $61 \cdot 7$ & $61 \cdot 8$ \\
\hline $\mathrm{NaCl}$ range for growth $(\mathrm{M})$ & $1 \cdot 5-4 \cdot 5$ & $1 \cdot 2-4 \cdot 9$ & $0 \cdot 05-3 \cdot 0$ & $0 \cdot 02-3 \cdot 3$ & $2-5$ & $2-5$ & $2-5$ \\
\hline $\mathrm{pH}$ range & $6 \cdot 7-8 \cdot 5$ & $6 \cdot 5-8 \cdot 4$ & $5 \cdot 5-9 \cdot 0$ & $4 \cdot 5-9 \cdot 6$ & $6 \cdot 7-8 \cdot 5$ & $6 \cdot 7-8 \cdot 5$ & $7 \cdot 0-8 \cdot 8$ \\
\hline \multicolumn{8}{|l|}{ Substrates: } \\
\hline Sugars & - & - & + & + & - & - & - \\
\hline Citrate & - & - & + & + & - & - & - \\
\hline Pyruvate & - & - & + & + & + & - & + \\
\hline Succinate & - & - & + & + & + & + & + \\
\hline Cell morphology & $\begin{array}{l}\text { Vibrios or } \\
\text { short spirilla }\end{array}$ & $\begin{array}{l}\text { Short spirilla with } \\
\text { a polar flagellum }\end{array}$ & $\begin{array}{l}\text { Straight, fat, } \\
\text { motile rods }\end{array}$ & $\begin{array}{l}\text { Fat rods with a } \\
\text { polar flagellum }\end{array}$ & $\begin{array}{l}\text { Long, flexible, } \\
\text { non-motile rods }\end{array}$ & $\begin{array}{l}\text { Short spirilla with a } \\
\text { single polar flagellum }\end{array}$ & $\begin{array}{l}\text { Short spirilla with a } \\
\text { single polar flagellum }\end{array}$ \\
\hline \multicolumn{8}{|l|}{$\begin{array}{l}\text { Anaerobic growth at } 2-4 \mathrm{M} \\
\mathrm{NaCl} \text { with: }\end{array}$} \\
\hline $\mathrm{NO}_{3}^{-}$ & + & - & - & - & + & + & + \\
\hline $\mathrm{NO}_{2}^{-}$ & - & $\mathrm{ND}$ & - & $\mathrm{ND}$ & + & + & + \\
\hline $\mathrm{N}_{2} \mathrm{O}$ & - & ND & - & $\mathrm{ND}$ & - & - & + \\
\hline Habitat & $\begin{array}{l}\text { Great Salt Lake, } \\
\text { UT, USA }\end{array}$ & $\begin{array}{l}\text { Great Salt Lake, } \\
\text { UT, USA }\end{array}$ & $\begin{array}{l}\text { Great Salt Lake, } \\
\text { UT, USA }\end{array}$ & $\begin{array}{l}\text { Great Salt Lake, } \\
\text { UT, USA }\end{array}$ & $\begin{array}{l}\text { Hypersaline lake, } \\
\text { SW Siberia }\end{array}$ & $\begin{array}{l}\text { Hypersaline lake, } \\
\text { NE Mongolia }\end{array}$ & $\begin{array}{l}\text { Hypersaline lake, } \\
\text { SW Siberia }\end{array}$ \\
\hline
\end{tabular}

ND, Not determined. 
(1990) have also reported on the chemical composition of $P$. halophila and Halovibrio variabilis, which confirmed their allocation to different higher taxa within the Proteobacteria.

DNA-DNA hybridization between the three vibrio-shaped denitrifying isolates and strain DSM 3050 showed moderate binding within the range 40-53\%, indicating different species and perhaps that they are members of the same genus. In contrast, the rod-shaped isolate HGD $1-3^{\mathrm{T}}$ showed a very low DNA-DNA hybridization level with all of the vibrio-shaped isolates and DSM 3050 (15-20\%).

The respiratory lipoquinones of all three isolates and DSM 3050 comprised only ubiquinones, with ubiquinone 9 predominating. The polar lipids of all three isolates and DSM 3050 were virtually identical to the pattern reported previously by Franzmann \& Tindall (1990), with diphosphatidylglycerol, phosphatidylglycerol, phosphatidylethanolamine and an unidentified amino-positive phospholipid comprising the major components. The fatty acid compositions of the isolates and DSM 3050 are given in Table 2.

When comparing the chemotaxonomy of the new isolates and DSM 3050 with organisms that, by 16S rRNA gene sequence analysis, group with these strains, it was noted that various published $16 \mathrm{~S}$ rRNA gene sequence-based neighbour-joining dendrograms all gave different topologies between the main groups examined (Baik et al., 2005; Yi et al., 2003; Yoon et al., 2004a, b; Lee et al., 2001). This is indicative of the fact that the 16S rRNA gene sequence data may not resolve absolute branching order and that the groupings should be given more significance than branching order. DSM 3050 and the novel strains all produced ubiquinone 9 as the sole respiratory quinone, a feature which they share with members of the genera Marinobacter, Pseudomonas, Halomonas, Cobetia, Carnimonas, Zymobacter, Hahella and Zooshikella (Garriga et al., 1998; Franzmann \& Tindall, 1990; Okamoto et al., 1993; Baik et al., 2005; Yi et al., 2003). It should be noted that members of the genera Microbulbifer and Marinobacter also produce ubiquinone 8 (Yoon et al., 2004a, b). Although the polar lipids phosphatidylglycerol and phosphatidylethanolamine are widely distributed in the Gammaproteobacteria, the presence of an unidentified aminophospholipid appears to be characteristic. The latter lipid is not present in Marinobacter hydrocarbonoclasticus (Spröer et al., 1998) and is also not a significant component of members of the genus Alcanivorax examined to date (B. J. Tindall, unpublished data). The polar lipid pofiles of members of the genera Halomonas and

Table 2. Fatty acid compositions (\%) of strains used in this study

Method M1 releases ester-linked fatty acids; method M2 releases ester- and amide-linked fatty acids. tr, Trace amount; -, below detection limit.

\begin{tabular}{|c|c|c|c|c|c|c|c|c|}
\hline \multirow[t]{2}{*}{ Fatty acid } & \multicolumn{2}{|c|}{ HGD $3^{T}$} & \multicolumn{2}{|c|}{ DSM 3050} & \multicolumn{2}{|c|}{ HGD $1-3^{T}$} & \multicolumn{2}{|c|}{ HGDK 5} \\
\hline & M1 & M2 & M1 & M2 & M1 & M2 & M1 & M2 \\
\hline $10: 0$ & $1 \cdot 915$ & $2 \cdot 124$ & $2 \cdot 086$ & $2 \cdot 483$ & $1 \cdot 622$ & $1 \cdot 498$ & $1 \cdot 708$ & $1 \cdot 738$ \\
\hline $12: 0$ & $\operatorname{tr}$ & $\operatorname{tr}$ & $0 \cdot 653$ & $0 \cdot 549$ & $1 \cdot 166$ & $1 \cdot 017$ & $0 \cdot 531$ & $0 \cdot 457$ \\
\hline $3-\mathrm{OH} 12: 0$ & $3 \cdot 345$ & $4 \cdot 138$ & $3 \cdot 614$ & $4 \cdot 046$ & $3 \cdot 361$ & $3 \cdot 419$ & $2 \cdot 381$ & $2 \cdot 733$ \\
\hline $14: 1^{\star}$ & $0 \cdot 844$ & $0 \cdot 737$ & $1 \cdot 515$ & $1 \cdot 336$ & $1 \cdot 234$ & $0 \cdot 985$ & $1 \cdot 172$ & $0 \cdot 947$ \\
\hline $14: 1$ & - & $0 \cdot 654$ & - & - & - & - & - & - \\
\hline $3-\mathrm{OH} 14: 1$ & - & - & - & - & $1 \cdot 058$ & $3 \cdot 054$ & - & - \\
\hline 3-OH 14:0 & - & $1 \cdot 743$ & - & $2 \cdot 399$ & - & - & - & $1 \cdot 906$ \\
\hline $16: 1^{\star}$ & - & - & - & - & $2 \cdot 673$ & $2 \cdot 093$ & - & - \\
\hline $16: 1 \omega 9 c$ & $3 \cdot 193$ & $2 \cdot 678$ & $4 \cdot 786$ & $4 \cdot 309$ & - & - & $4 \cdot 308$ & $3 \cdot 781$ \\
\hline $16: 1 \omega 7 c$ & $5 \cdot 22$ & $5 \cdot 61$ & - & - & - & - & - & - \\
\hline $16: 1$ & - & - & $0 \cdot 451$ & $0 \cdot 422$ & $1 \cdot 467$ & $1 \cdot 248$ & $0 \cdot 71$ & $0 \cdot 596$ \\
\hline $16: 0$ & $15 \cdot 396$ & $14 \cdot 446$ & $15 \cdot 356$ & $14 \cdot 047$ & $7 \cdot 984$ & $7 \cdot 353$ & $14 \cdot 303$ & $13 \cdot 152$ \\
\hline Unidentified & $8 \cdot 022$ & $7 \cdot 139$ & $8 \cdot 109$ & $8 \cdot 495$ & $6 \cdot 817$ & $6 \cdot 893$ & $11 \cdot 303$ & $11 \cdot 105$ \\
\hline $18: 1$ & - & - & - & - & - & $0 \cdot 305$ & - & - \\
\hline $18: 1 \omega 9 c$ & $46 \cdot 557$ & $41 \cdot 919$ & $55 \cdot 227$ & $53 \cdot 167$ & $65 \cdot 522$ & $63 \cdot 651$ & $53 \cdot 709$ & $52 \cdot 255$ \\
\hline $18: 1 \omega 7 c$ & $10 \cdot 182$ & $11 \cdot 877$ & $0 \cdot 915$ & $0 \cdot 899$ & - & - & $0 \cdot 893$ & $0 \cdot 892$ \\
\hline Unidentified & - & - & - & - & $0 \cdot 62$ & $0 \cdot 599$ & - & - \\
\hline $18: 0$ & $3 \cdot 317$ & $3 \cdot 352$ & $3 \cdot 134$ & $3 \cdot 346$ & $5 \cdot 451$ & $6 \cdot 304$ & $3 \cdot 671$ & $4 \cdot 144$ \\
\hline Unidentified & - & $0 \cdot 849$ & $0 \cdot 691$ & $0 \cdot 641$ & $1 \cdot 025$ & $0 \cdot 89$ & $0 \cdot 655$ & $0 \cdot 605$ \\
\hline 10-Methyl $18: 0$ & $2 \cdot 009$ & $2 \cdot 077$ & $3 \cdot 463$ & $3 \cdot 861$ & - & $0 \cdot 451$ & $4 \cdot 656$ & $5 \cdot 689$ \\
\hline Unidentified & - & $0 \cdot 657$ & - & - & - & - & - & - \\
\hline Unidentified & - & - & - & - & - & $0 \cdot 24$ & - & - \\
\hline
\end{tabular}

${ }^{\star}$ The exact location of the double bond was not determined. 
Cobetia are more complex (Franzmann \& Tindall, 1990). The polar lipid compositions of members of the genera Microbulbifer, Hahella and Zooshikella have not been reported to date. The fatty acids were characterized by the presence of straight-chain saturated and unsaturated components, with $16: 0$ and various isomers of $16: 1$ and $18: 1$ predominating. However, the dominance of such fatty acids is fairly typical of a large number of taxa within the Betaproteobacteria and Gammaproteobacteria and discrimination at the genus level depends on the evaluation of the other components. All strains contained a 3-OH 12:0 fatty acid, which appeared to be exclusively ester-linked, whereas the presence of 3-OH 14:0, which appeared to be amide-linked, was characteristic of strains HGD $3^{\mathrm{T}}$, DSM 3050 and HGDK 5. In contrast, strain HGD $1-3^{\mathrm{T}}$ contained a $3-\mathrm{OH} 14: 1$ fatty acid, which appeared to be ester- and amide-linked in the ratio $1: 2$. The presence of both ester-linked and amidelinked fatty acids is in contrast to the presence of 3-OH 12:0 in Marinobacter hydrocarbonoclasticus, which appears to be exclusively amide-linked (Spröer et al., 1998). The presence of an amide-linked 3-OH 12:0 in other members of the genus Marinobacter (Romanenko et al., 2005; Yoon et al., 2004b) may be inferred from the work of Gorshkova et al. (2003). 3-OH 12:0 also appears to be present in members of the genera Alcanivorax, Hahella and Zooshikella (Liu \& Shao, 2005; Baik et al., 2005; Yi et al., 2003), although no data are available to date on the nature of the chemical linkage. The absence of this fatty acid in Alcanivorax borkumensis is simply due to the fact that Yakimov et al. (1998) only examined a selected lipid fraction, which would not have included the lipopolysaccharide. Members of the genus Pseudomonas contain both 3-OH 10:0 (ester-linked) and 3-OH 12:0 (amide-linked) (see Wilkinson, 1988 for an overview; Vancanneyt et al., 1996). In addition, some species of this genus also contain a 2-OH 12:0 fatty acid (Vancanneyt et al., 1996). Carnimonas nigrificans contains a 3-OH 14:0 and a 2-OH 12:0 fatty acid (Garriga et al., 1998; C. Belloch and B. J. Tindall, unpublished), whereas members of the genera Halomonas, Chromohalobacter, Cobetia and Zymobacter contain 3-OH 12:0, which appears to be both amide- and ester-linked (C. Belloch and B. J. Tindall, unpublished). Members of the genus Zooshikella contain 3-OH 10:0, 3-OH 12:0 and small amounts of 3-OH 12:1 (Yi et al., 2003), whereas members of the genus Hahella contain 3-OH 12:0 (Lee et al., 2001; Baik et al., 2005). These differences are probably due to differences in the structures of the lipopolysaccharides, but this would need to be verified by independent research. The distribution of the various unsaturated fatty acids also appears to be indicative of differences between strains HGD $3^{\mathrm{T}}$, HGD $1-3^{\mathrm{T}}$ and DSM 3050, as well as between members of the genera Halomonas, Cobetia, Carnimonas, Zymobacter (Franzmann \& Tindall, 1990; Garriga et al., 1998; Okamoto et al., 1993), Marinobacter (Gorshkova et al., 2003; Romanenko et al., 2005; Spröer et al., 1998; Yoon et al., 2004b) and Alcanivorax. Whereas $16: 1 \omega 7 c$ and $18: 1 \omega 7 c$ appear to predominate in members of the genera Zooshikella, Halomonas, Cobetia, Carnimonas, Zymobacter and Alcanivorax, these two fatty acids are also present in members of the genera Marinobacter and Hahella (Baik et al., 2005), but 16:1109c and $18: 1 \omega 9 c$ generally predominate in members of these genera. The patterns in strains HGD $3^{\mathrm{T}}$ and DSM 3050 are similar to those of members of the genera Hahella and Marinobacter, but strain HGD $1-3^{\mathrm{T}}$ does not appear to contain either $16: 1 \omega 7 c$ or $16: 1 \omega 9 c$. Members of the genus Microbulbifer are characterized by the presence of largely iso- and straight-chain saturated fatty acids, as well as 3-OH 10:0 and 3-OH iso-11:0 (Yoon et al., 2004a). Taken together, the chemical compositions of the novel isolates provide a useful dataset for distinguishing between the strains examined here and the members of those genera that share a high degree of $16 \mathrm{~S}$ rRNA gene sequence similarity. These similarities and differences provide evidence in support of the use of the chemical composition of the cell to investigate evolutionary relationships within the prokaryotes (Tindall, 1994).

Overall, the data presented demonstrate that the novel, extremely halophilic gammaproteobacteria isolated from hypersaline lakes in Central Asia include two different groups. The three vibrio-shaped strains are closely related to the extremely halophilic bacterium originally described as Halovibrio variabilis, but currently listed under the name P. halophila (DSM 3050). This indicates that the circumscription of the species $P$. halophila does not coincide with the properties of the type (and only) strain of this species, DSM 3050. The same is true of the circumscription of the species Halovibrio variabilis (which is considered to be a member of the genus Halomonas) and the properties of its type (and only) strain, DSM 3051. Under Rule 18g of the Bacteriological Code (Lapage et al., 1992), such matters must be referred to the Judicial Commission and in an accompanying paper we have outlined the problem in detail, together with a formal request that DSM 3050 be recognized as the type strain of Halovibrio variabilis (Sorokin \& Tindall, 2006). This would also have the effect of placing the type strain of that species and the genus Halovibrio outside of the genus Halomonas. Any novel species placed in the same genus as DSM 3050 would consequently be placed in the genus Halovibrio and not in a new genus. While the status of the genus name Halovibrio and the species name Halovibrio variabilis depends on the way the problem with the strains DSM 3050 and DSM 3051 is handled by the Judicial Commission, it also creates a problem for the recognition of a novel species that is to be placed in the same genus as DSM 3050 .

On the basis of phenotypic and genetic properties, the new vibrio-shaped denitrifying isolates are clearly similar in their properties to the published description of Halovibrio variabilis (Fendrich, 1988) and to DSM 3050. However, these isolates are also clearly members of a novel species. A consequence of species names being combinations is that a novel species must by definition be placed in a genus. In this particular case, we consider that we are justified in providing the following solution. The novel species should be placed in 
the genus whose circumscription corresponds with that of the novel strains, i.e. the genus Halovibrio. However, this also depends on the Judicial Commission accepting that DSM 3050 fits the circumscription of Halovibrio variabilis and designating this as the type strain of the species. Consequently, although we have provided a formal description for a novel species within the genus Halovibrio, which conforms to the present Rules of the Bacteriological Code, we also recognize that this name anticipates the action of the Judicial Commission and that the name cannot currently be considered to be validly published, as outlined in Rule $28 \mathrm{~b}$ (2) of the Bacteriological Code (Lapage et al., 1992). Equally, in submitting a Request for an Opinion, this would also preclude that DSM 3050 be placed in a new genus until the Judicial Commission has published its Opinion. Both aspects are dealt with in an accompanying paper (Sorokin \& Tindall, 2006).

Below we present formal descriptions of the vibrio-shaped strains as representing a novel species of the genus Halovibrio, Halovibrio denitrificans sp. nov., and an emended description of the genus Halovibrio. In addition, the rodshaped, extremely halophilic, denitrifying strain HGD 1-3 ${ }^{\mathrm{T}}$ is proposed to represent a new genus and species, Halospina denitrificans gen. nov., sp. nov.

\section{Emended description of the genus Halovibrio}

The emended description is based on data collected during this study and on data published previously by Franzmann \& Tindall (1990) using DSM 3050 (=P. halophila).

The description is based on data published by Fendrich (1988) on DSM 3050. In addition, ubiquinone 9 is the major respiratory lipoquinone, the major polar lipids are diphosphatidylglycerol, phosphatidylglycerol, phosphatidylethanolamine and an unidentified amino-positive phospholipid. The $R_{\mathrm{f}}$ of this latter compound is important. Fatty acids present are $10: 0,12: 0,3-\mathrm{OH} 12: 0$ (ester-linked), 14:1, 3-OH $14: 0$ (amide-linked), 16:1 $1 \omega 9 c, 16: 0,18: 1 \omega 9 c, 18: 0$,

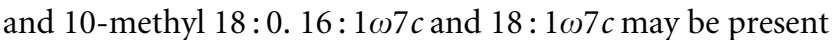
in varying amounts. The genus comprises two species, Halovibrio variabilis Fendrich 1989 and Halovibrio denitrificans.

\section{Description of Halovibrio denitrificans sp. nov.}

Halovibrio denitrificans (de.ni.tri'fi.cans. N.L. v. denitrifico to denitrify; N.L. part. adj. denitrificans denitrifying).

Cells are vibrios or short spirilla, motile with a single polar flagellum, $0 \cdot 5-0.8 \times 1 \cdot 5-4 \mu \mathrm{m}$; in old cultures the cell edges become transparent. Extremely halophilic with $\mathrm{NaCl}$ range for growth between 2.0 and $5 \mathrm{M}$ and an optimum at $2 \cdot 0-2 \cdot 5 \mathrm{M}$. Facultatively anaerobic. Grows anaerobically with nitrate as electron acceptor and short-chain fatty acids as electron donors/carbon source, producing nitrite and $\mathrm{N}_{2} \mathrm{O}$ as intermediates. Sugars are not utilized. Some strains can grow with $\mathrm{N}_{2} \mathrm{O}$ as electron acceptor. Oxidizes thiosulfate to tetrathionate during aerobic heterotrophic growth. Produces glycine betaine (major) and ectoine (minor) as compatible solutes. The chemical composition is identical to that given in the emended genus description. The $\mathrm{G}+\mathrm{C}$ content of the DNA is $61 \cdot 8 \pm 0 \cdot 5 \mathrm{~mol} \%\left(T_{\mathrm{m}}\right)$.

The type strain, HGD $3^{\mathrm{T}}\left(=\mathrm{DSM} 15503^{\mathrm{T}}=\mathrm{UNIQEM}\right.$ $\mathrm{U} 232^{\mathrm{T}}$ ), was isolated from sediments of the hypersaline lake Barun-Davst-Nur in north-eastern Mongolia.

\section{Description of Halospina gen. nov.}

Halospina [Ha.lo.spi'na. Gr. n. hals, halos salt; L. n. spina spine; N.L. masc. n. Halospina a salt (loving) spine (long thin rod)].

Rod-shaped, Gram-negative, extremely halophilic gammaproteobacteria, with highest $16 \mathrm{~S}$ rRNA gene sequence similarity to members of the halophilic genera Marinobacter and Alcanivorax. Facultatively anaerobic. Produce glycine betaine (major) and ectoine (minor) as compatible solutes. Ubiquinone 9 is the major respiratory lipoquinone. The major polar lipids are diphosphatidylglycerol, phosphatidylglycerol, phosphatidylethanolamine and an unidentified amino-positive phospholipid. The $R_{\mathrm{f}}$ of this latter compound is important. Fatty acids present are 10:0, 12:0, 3-OH 12:0 (ester-linked), 14:1, 3-OH 14:1 (ester- and amide-linked), two different $16: 1$ isomers, $16: 0,18: 1 \omega 9 c$, $18: 0$ and 10 -methyl $18: 0$. The $\mathrm{G}+\mathrm{C}$ content of the DNA of the type species is $60 \pm 0.5 \mathrm{~mol} \%\left(T_{\mathrm{m}}\right)$. Habitats are hypersaline lakes. The type and only species is Halospina denitrificans.

\section{Description of Halospina denitrificans sp. nov.}

Halospina denitrificans (de.ni.tri'fi.cans. N.L. v. denitrifico to denitrify; N.L. part. adj. denitrificans denitrifying).

Cells are long, flexible, non-motile rods with tapered edges, $0 \cdot 7-1 \cdot 0 \times 3-7 \mu \mathrm{m}$. Extremely halophilic with $\mathrm{NaCl}$ range for growth between $2 \cdot 0$ and $5 \mathrm{M}$ and an optimum at 2.5-3.0 M. Facultatively anaerobic. Grows aerobically and anaerobically with nitrate as electron acceptor and short-chain fatty acids as electron donors/carbon source, producing nitrite and $\mathrm{N}_{2} \mathrm{O}$ as intermediates. Sugars are not utilized. Oxidizes thiosulfate to tetrathionate during aerobic heterotrophic growth. Produces glycine betaine (major) and ectoine (minor) as compatible solutes. The chemical composition is identical to that given in the genus description. The $\mathrm{G}+\mathrm{C}$ content of the DNA is $60 \cdot 1 \pm 0 \cdot 5 \mathrm{~mol} \%\left(T_{\mathrm{m}}\right)$.

The type strain, HGD $1-3^{\mathrm{T}}$ (=DSM $15505^{\mathrm{T}}=$ UNIQEM $\mathrm{U}_{23} 3^{\mathrm{T}}$ ), was isolated from sediments of a hypersaline salt lake in Kulunda Steppe (Altai, Russia).

\section{Acknowledgements}

D. Yu. S. was supported by the NWO-RFBR (grant 47.011.2004.010) and by the programme of the Russian Academy of Sciences 'Molecular and Cell Biology'. C. B. was supported by a postdoctoral fellowship from the Spanish 'Ministerio de Educación y Ciencia'. B. J.T. would like to thank Dr Manfred Nimtz and Claudia Hanko, GBF, 
Braunschweig, for access to and support in running the GC-MS. We thank M. Stein for technical assistance in determination of compatible solutes.

\section{References}

Anzai, Y., Kim, H., Park, J.-Y., Wakabayashi, H. \& Oyaizu, H. (2000). Phylogenetic affiliation of the pseudomonads based on 16S rRNA sequence. Int J Syst Evol Microbiol 50, 1563-1589.

Baik, K. S., Seong, C. N., Kim, E. M., Yi, H., Bae, K. S. \& Chun, J. (2005). Hahella ganghwensis sp. nov., isolated from tidal flat sediment. Int J Syst Evol Microbiol 55, 681-684.

Clifford, D. \& Liu, X. (1993). Ion exchange for nitrate removal. AWWA J 85, 135-142.

De Ley, J., Cattoir, H. \& Reynaerts, A. (1970). The quantitative measurement of DNA hybridization from renaturation rates. Eur J Biochem 12, 133-140.

Dobson, S. J. \& Franzmann, P. D. (1996). Unification of the genera Deleya (Baumann et al. 1983), Halomonas (Vreeland et al. 1980), and Halovibrio (Fendrich 1988) and the species Paracoccus halodenitrificans (Robinson and Gibbons 1952) into a single genus, Halomonas, and placement of the genus Zymobacter in the family Halomonadaceae. Int J Syst Bacteriol 46, 550-558.

Dobson, S. J., McMeekin, T. A. \& Franzmann, P. D. (1993). Phylogenetic relationships between some members of the genera Deleya, Halomonas, and Halovibrio. Int J Syst Bacteriol 43, 665-673.

Felsenstein, J. (1989). PHYLIP - phylogenetic inference package (version 3.2). Cladistics 5, 164-166.

Fendrich, C. (1988). Halovibrio variabilis gen. nov. sp. nov., Pseudomonas halophila sp. nov. and new halophilic aerobic coccoid Eubacterium from Great Salt Lake, Utah, USA. Syst Appl Microbiol 11, 36-43.

Franzmann, P. D. \& Tindall, B. J. (1990). A chemotaxonomic study of members of the family Halomonadaceae. Syst Appl Microbiol 13, 142-147.

Galinski, E. A. (1995). Osmoadaptation in bacteria. Adv Microb Physiol 37, 272-328.

Galinski, E. A. \& Herzog, R. M. (1990). The role of trehalose as a substitute for nitrogen-containing compatible solutes (Ectothiorhodospira halochloris). Arch Microbiol 153, 607-613.

Garriga, M., Ehrmann, M. A., Arnau, J., Hugas, M. \& Vogel, R. F. (1998). Carnimonas nigrificans gen. nov., sp. nov., a bacterial causative agent for black spot formation on cured meat products. Int J Syst Bacteriol 48, 677-686.

Gorshkova, N. M., Ivanova, E. P., Sergeev, A. F., Zhukova, N. V., Alexeeva, Y., Wright, J. P., Nicolau, D. V., Mikhailov, V. V. \& Christen, R. (2003). Marinobacter excellens sp. nov., isolated from sediments of the Sea of Japan. Int J Syst Evol Microbiol 53, 2073-2078.

Jukes, T. H. \& Cantor, C. R. (1969). Evolution of protein molecules. In Mammalian Protein Metabolism, pp. 21-132. Edited by H. N. Munro. New York: Academic Press.

Labrenz, M., Collins, M. D., Lawson, P. A., Tindall, B. J., Braker, G. \& Hirsch, P. (1998). Antarctobacter heliothermus gen. nov., sp. nov., a budding bacterium from hypersaline and heliothermal Ekho Lake. Int J Syst Bacteriol 48, 1363-1372.

Lapage, S. P., Sneath, P. H. A., Lessel, E. F., Skerman, V. B. D., Seeliger, H. P. R. \& Clark, W. A. (editors) (1992). International Code of Nomenclature of Bacteria (1990 Revision): Bacteriological Code. Washington, DC: American Society for Microbiology.

Lee, H. K., Chun, J., Moon, E. Y., Ko, S.-H., Lee, D.-S., Lee, H. S. \& Bae, K. S. (2001). Hahella chejuensis gen. nov., sp. nov., an extracellular-polysaccharide-producing marine bacterium. Int J Syst Evol Microbiol 51, 661-666.
Liu, C. \& Shao, Z. (2005). Alcanivorax dieselolei sp. nov., a novel alkane-degrading bacterium isolated from sea water and deep-sea sediment. Int J Syst Evol Microbiol 55, 1181-1186.

Marmur, J. (1961). A procedure for the isolation of deoxyribonucleic acid from microorganisms. J Mol Biol 3, 208-218.

Okamoto, T., Taguchi, H., Nakamura, K., Ikenaga, H., Kuraishi, H. \& Yamasato, K. (1993). Zymobacter palmae gen. nov., sp. nov., a new ethanol-fermenting peritrichous bacterium isolated from palm sap. Arch Microbiol 160, 333-337.

Oren, A. (2002). Halophilic Microorganisms and their Environments. Dordrecht: Kluwer Academic.

Pfennig, N. \& Lippert, K. D. (1966). Über das Vitamin $B_{12}-$ bedürfnis phototropher Schwefel bacterien. Arch Mikrobiol 55, 245-256 (in German).

Romanenko, L. A., Schumann, P., Rohde, M., Zhukova, N. V., Mikhailov, V. V. \& Stackebrandt, E. (2005). Marinobacter bryozoorum sp. nov. and Marinobacter sediminum sp. nov., novel bacteria from the marine environment. Int J Syst Evol Microbiol 55, 143-148.

Sorokin, D. Yu. \& Tindall, B. J. (2006). The status of the genus name Halovibrio Fendrich 1989 and the identity of the strains Pseudomonas halophila DSM 3050 and Halomonas variabilis DSM 3051. Request for an Opinion. Int J Syst Evol Microbiol 56, 487-489.

Sorokin, D. Yu., Kuenen, J. G. \& Jetten, M. S. M. (2001). Denitrification at extremely high $\mathrm{pH}$ values by the alkaliphilic, obligately chemolithoautotrophic, sulfur-oxidizing bacterium Thioalkalivibrio denitrificans strain ALJD. Arch Microbiol 175, 94-101.

Spröer, C., Lang, E., Hobeck, P., Burghardt, J., Stackebrandt, E. \& Tindall, B. J. (1998). Transfer of Pseudomonas nautica to Marinobacter hydrocarbonoclasticus. Int J Syst Bacteriol 48, 1445-1448.

Strömpl, C., Tindall, B. J., Jarvis, G. N., Lünsdorf, H., Moore, E. R. B. \& Hippe, H. (1999). A re-evaluation of the taxonomy of the genus Anaerovibrio, with the reclassification of Anaerovibrio glycerini as Anaerosinus glycerini gen. nov., comb. nov., and Anaerovibrio burkinabensis as Anaeroarcus burkinabensis [corrig.] gen. nov., comb. nov. Int J Syst Bacteriol 49, 1861-1872.

Tindall, B. J. (1990). Lipid composition of Halobacterium lacusprofundi. FEMS Microbiol Lett 66, 199-202.

Tindall, B. J. (1994). Chemical analysis of archaea and bacteria: a critical evaluation of its use in taxonomy and identification. In Bacterial Diversity and Systematics (FEMS Symposium no. 75), pp. 243-258. Edited by F. G. Priest, A. Ramos-Cormenzana \& B. J. Tindall. New York: Plenum Press.

Vancanneyt, M., Witt, S., Abraham, W.-R., Kersters, K. \& Fredrickson, H. L. (1996). Fatty acid content in whole-cell hydrolysates and phospholipid fractions of pseudomonads: a taxonomic evaluation. Syst Appl Microbiol 19, 528-540.

Van de Peer, Y. \& De Wachter, R. (1994). TREECON for Windows: a software package for the construction and drawing of evolutionary trees for the Microsoft Windows environment. Comput Appl Biosci 10, 569-570.

Ventosa, A., Nieto, J. J. \& Oren, A. (1998). Biology of moderately halophilic aerobic bacteria. Microbiol Mol Biol Rev 62, 504-544.

Wilkinson, S. G. (1988). Gram-positive bacteria. In Microbial Lipids, pp. 117-201. Edited by C. Ratledge \& S. G. Wilkinson. London: Academic Press.

Wohlfarth, A., Severin, J. \& Galinski, E. A. (1990). The spectrum of compatible solutes in heterotrophic halophilic eubacteria of the family Halomonadaceae. J Gen Microbiol 136, 705-712.

Yakimov, M. M., Golyshin, P. N., Lang, S., Moore, E. R. B., Abraham, W.-R., Lünsdorf, H. \& Timmis, K. N. (1998). Alcanivorax borkumensis gen. nov., sp. nov., a new, hydrocarbon-degrading and surfactantproducing marine bacterium. Int J Syst Bacteriol 48, 339-348. 
Yi, H., Chang, Y.-H., Oh, H. W., Bae, K. S. \& Chun, J. (2003). Zooshikella ganghwensis gen. nov., sp. nov., isolated from tidal flat sediments. Int J Syst Evol Microbiol 53, 1013-1018.

Yoon, J.-H., Kim, I.-G., Oh, T.-K. \& Park, Y.-H. (2004a). Microbulbifer maritimus sp. nov., isolated from an intertidal sediment from the Yellow Sea, Korea. Int J Syst Evol Microbiol 54, 1111-1116.
Yoon, J.-H., Yeo, S.-H., Kim, I.-G. \& Oh, T.-K. (2004b). Marinobacter flavimaris sp. nov. and Marinobacter daepoensis sp. nov., slightly halophilic organisms isolated from sea water of the Yellow Sea in Korea. Int J Syst Evol Microbiol 54, 1799-1803.

Zumft, W. G. (1997). Cell biology and molecular basis of denitrification. Microbiol Mol Biol Rev 61, 533-616. 